Web Jurnal:

http://ejournal.kemenperin.go.id/jli

\title{
Degradasi senyawa fenol secara fotokatalisis dengan menggunakan katalis C-doped $\mathrm{TiO}_{2}$
}

\section{Degradation of phenol by photocatalysis using $\mathrm{C}$-doped $\mathrm{TiO}_{2}$ catalyst}

\section{S Safni*1, Vepilia Wulanda ${ }^{1}$, K Khoiriah', Diana Vanda Wellia ${ }^{2}$}

1 Laboratorium Kimia Analisis Terapan, Jurusan Kimia, Fakultas Matematika dan Ilmu Pengetahuan Alam, Universitas Andalas, Kota Padang, Sumatera Barat 25163

2 Laboratorium Kimia Material, Jurusan Kimia, Fakultas Matematika dan Ilmu Pengetahuan Alam, Universitas Andalas, Kota Padang, Sumatera Barat 25163

* e-mail: safni@sci.unand.ac.id

\begin{tabular}{|c|c|}
\hline INFO ARTIKEL & ABSTRAK \\
\hline Sejarah artikel: & Fenol merupakan senyawa kimia yang banyak digunakan dalam proses industri. Akan \\
\hline Diterima: & tetapi fenol dalam konsentrasi berlebihan dapat menimbulkan efek buruk terhadap \\
\hline 4 Februari 2019 & kehidupan manusia dan lingkungan pada umumnya. Pada penelitian ini, fenol didegradasi \\
\hline Direvisi: & secara fotolisis tanpa dan dengan menggunakan katalis $\mathrm{C}$-doped $\mathrm{TiO}_{2}$ di bawah sinar \\
\hline 28 Mei 2019 & UV (10 Watt, $\lambda=365 \mathrm{~nm}$ ) dan sinar tampak (lampu philips LED 13 watt 1400 lux, $\lambda=$ \\
\hline Diterbitkan: & 465-640 nm). Larutan fenol yang telah didegradasi diukur dengan Spektrofotometer UV- \\
\hline & $\begin{array}{l}\text { Vis pada panjang gelombang } 200-400 \mathrm{~nm} \text {. Hasil karakterisasi XRD dan DRS UV-Vis } \\
\text { memperlihatkan bahwa katalis modifikasi titania menggunakan unsur karbon berpotensi }\end{array}$ \\
\hline Kata kunci: & dari degradasi fenol pada sistem fotolisis. Larutan fenol $8 \mathrm{mg} / \mathrm{L}$ terdegradasi sebanyak \\
\hline $\begin{array}{l}\text { C-doped } \mathrm{TiO}_{2} \\
\text { degradasi; } \\
\text { fenol; }\end{array}$ & $\begin{array}{l}38,98 \% \text { dan } 35,59 \% \text { tanpa katalis dan meningkat menjadi } 51,69 \% \text { dan } 66,10 \% \text { dengan } \\
\text { penambahan } 5 \mathrm{mg} \text { katalis } \mathrm{C} \text {-doped } \mathrm{TiO}_{2} \text { masing-masing di bawah sinar UV dan sinar } \\
\text { tampak. }\end{array}$ \\
\hline
\end{tabular}

Keywords:

C-doped TiO2;

degradation;

phenol;

photolysis

\begin{abstract}
Phenol is a chemical compound that is widely used in industrial processes. However, phenol in excessive concentration can endanger human life and the environment. In this study, phenol was degraded without and using $\mathrm{C}$-doped $\mathrm{TiO}_{2}$ catalyst under $\mathrm{UV}$-light (10 Watts, $\lambda=365 \mathrm{~nm}$ ) and visible-light (13 watt Philips, lux=1400, $\lambda=465-640 \mathrm{~nm}$ ) photolysis. The degraded of phenol solution was measured by a UV-Vis spectrophotometer at a wavelength 200-400 $\mathrm{nm}$. The results of XRD and DRS UV-Vis characterization show that the modified of titania catalyst using carbon potentially actives in visible-light. Application of $\mathrm{C}$-doped $\mathrm{TiO}_{2}$ catalyst can improve the efficiency of phenol degradation in photolysis system. Phenol solution with concentration $8 \mathrm{mg} / \mathrm{L}$ was degraded by $38.98 \%$ and $35.59 \%$ without catalyst and increased to be $51.69 \%$ and $66.10 \%$ in presence of $5 \mathrm{mg} \mathrm{C}$-doped $\mathrm{TiO}_{2}$ catalyst under $\mathrm{UV}$-light and visible-light, respectively.
\end{abstract}

(C) 2019 Penulis. Dipublikasikan oleh Baristand Industri Padang. Akses terbuka di bawah lisensi CC BY-NC-SA

\section{Pendahuluan}

Fenol adalah senyawa hidroksibenzen beracun yang bersumber dari industri proses kimia seperti produksi herbisida dan fungisida, gasifikasi batubara, pabrik kertas, pabrik kokas produksi resin polimer, pemurnian minyak, industri cat, tekstil, industri pengolahan makanan dan bioteknologi (Borji et al., 2014; Jyothi, 2016). Paparan terhadap manusia dapat terjadi melalui penyerapan melalui kulit, menelan, adsorpsi kulit, dan inhalasi (Wiley and Sons, 2003; Meena et al., 2015). Fenol juga dapat menyebabkan luka bakar pada area kulit, kelumpuhan sistem saraf pusat dan penurunan suhu tubuh yang parah, serta menyebabkan kerusakan organ dalam yaitu ginjal, hati, limpa, paru-paru dan jantung (Wiley and Sons, 2003). Toksisitas fenol dapat mempengaruhi mikroorganisme akuatik dan dapat mematikan ikan pada konsentrasi 5-25 mg/L. Oleh 
karena itu, konsentrasi fenol tidak boleh melebihi $1 \mu \mathrm{g} / \mathrm{L}$ pada air minum dan $1 \mathrm{mg} / \mathrm{L}$ pada perairan berdasarkan peraturan yang dikeluarkan oleh Organisasi Kesehatan Dunia (WHO) (Yunus et al., 2017) dan Badan Perlindungan Lingkungan (EPA) (Kumar and Min, 2011).

Beberapa metode konvensional seperti metode fisika (adsorpsi karbon aktif, filtrasi, dan osmosis balik), metode kimia (pertukaran ion, ekstraksi pelarut dan elektrokimia) dan metode biologi (proses aerobik dan anaerob) (Abdelwahab et al., 2009) telah dilaporkan untuk mengatasi limbah yang mengandung fenol. Akan tetapi metode-metode tersebut masih memerlukan beberapa tahap pemrosesan, biaya tinggi, efisiensi rendah dan masih menghasilkan limbah sekunder. (Borji et al., 2014).

Fotokatalisis adalah salah satu metode dari teknik proses oksidasi lanjut (AOPs) yang paling banyak dikembangkan dalam degradasi polutan organik. Metode ini dilaporkan efektif dalam degradasi zat warna (Mariappan et al., 2014; Safni et al., 2015a; Safni et al., 2015b; Safni et al., 2017) dan pestisida (Arfi et al., 2018). Sistem ini menggabungkan peran katalis semikonduktor dan cahaya sebagai sumber foton. Ketika katalis disinari energi foton yang sama atau lebih besar dari band gap katalis, elektron dari katalis akan tereksitasi dari pita valensi ke pita konduksi. Proses ini menghasilkan hole dan electron. Selanjutnya hole akan bereaksi dengan gugus hidroksil dari molekul air membentuk radikal hidroksil. Radikal hidroksil akan bertindak sebagai oksidator kuat untuk degradasi senyawa fenol. Produk akhir yang diharapkan dari proses ini adalah senyawa yang lebih sederhana dan lebih ramah lingkungan seperti $\mathrm{CO}_{2}$ dan $\mathrm{H}_{2} \mathrm{O}$ (Safni et al., 2017; Sharma et al., 2011).

Titania $\left(\mathrm{TiO}_{2}\right)$ adalah katalis semikonduktor yang paling umum digunakan dalam proses fotokatalisis dengan beberapa keunggulan yaitu tidak beracun, murah dan memiliki stabilitas tinggi (Wellia et al., 2018; Gupta and Tripathi, 2011). Akan tetapi titania memiliki celah pita (band gap) yang cukup besar $(3,2 \mathrm{eV})$ dan hanya bisa aktif di bawah sinar berenergi tinggi seperti sinar UV.

Modifikasi dengan cara doping adalah salah satu opsi agar titania bisa aktif pada sinar tampak dengan harapan bisa diaplikasikan pada sumber sinar yang lebih ekonomis seperti sinar matahari. Unsur potensial yang bisa digunakan untuk modifikasi titania adalah karbon. Unsur ini memiliki energi ionisasi yang kecil, ukurannya tidak jauh berbeda dari oksigen dan juga dapat mempersempit energi celah pita sehingga dapat digunakan di bawah cahaya matahari (Teh and Mohamed, 2011). Karbon berfungsi sebagai photosensitizer yang menyebabkan titania sensitif terhadap cahaya sinar tampak (Khalid et al., 2017).

Sejauh ini, belum ada laporan mengenai aplikasi Cdoped $\mathrm{TiO}_{2}$ yang disintesis dengan metode peroxo solgel dalam mengatasi senyawa fenol. Oleh karena itu, tujuan dari penelitian ini adalah memodifikasi titania dengan karbon menggunakan metode peroxo sol-gel yang ramah lingkungan (bebas pelarut organik). Katalis diaplikasikan dalam mendegradasi senyawa fenol secara fotokatalisis. Beberapa parameter yang dipelajari yaitu; pengaruh jumlah penambahan massa katalis, pengaruh jenis sumber sinar, dan pengaruh waktu iradiasi.

\section{Metode}

Bahan-bahan yang digunakan pada penelitian ini yaitu fenol (Merck), bubuk karbon (Sigma - Aldrich), natrium hidroksida p.a, $\mathrm{TiCl}_{4}$ (Merck), hidrogen peroksida (Merck) dan akuades. Peralatan yang digunakan adalah Spektrofotometer Ultraviolet-Visible (Thermo Scientific Evolution $201 \quad U V$-Vis Spectrophotometer), neraca analitik (AA-200, Denver Instrument Company), Lampu UV 10 watt $(\lambda=365 \mathrm{~nm})$, lampu sinar tampak (Philips LED 13 watt 1400 Lux, $\lambda=$ 465-640 nm), sentrifus (NASCO dengan kecepatan 3000 rpm), High Performance Liquid Chromatography (HPLC-Shimadzu), pH meter, pemanas, kotak iradiasi, magnetic stirrer.

\subsection{Pembuatan katalis C-doped $\mathrm{TiO}_{2}$}

Bubuk karbon sebanyak 0,2616 g dilarutkan dengan akuades sebanyak $300 \mathrm{~mL}$ lalu diultrasonifikasi selama 1 jam. Campuran ditambahkan dengan $\mathrm{TiCl}_{4} \quad 3,6 \mathrm{~mL}$ setetes demi setetes dalam ice bath sambil diaduk. $\mathrm{pH}$ diatur menjadi 10 dengan penambahan $\mathrm{NaOH} 5 \mathrm{~N}$ setetes demi setetes. Setelah 24 jam diperoleh endapan yang kemudian disentrifus dan dicuci dengan akuades berulang hingga tidak terdeteksi $\mathrm{Cl}^{-}$. Endapan dilarutkan dalam akuades $80 \mathrm{~mL}$ lalu ditambahkan $\mathrm{H}_{2} \mathrm{O}_{2} 28 \mathrm{~mL}$ setetes demi setetes ke dalam campuran sambil diaduk. Larutan dikeringkan dalam oven. Selanjutnya sampel dikalsinasi pada suhu $500^{\circ} \mathrm{C}$ selama 1 jam untuk memperoleh kristal C-doped $\mathrm{TiO}_{2}$ anatase.

\subsection{Karakterisasi katalis}

Katalis yang didapatkan dilakukan karakterisasi dengan menggunakan peralatan $X$-Rays Diffraction (XRD) dan Diffuse-Reflactance Spectrometry Ultraviolet-Visible (DRS UV-Vis).

\subsection{Pembuatan dan pengukuran spektrum serapan fenol}

Fenol $0,1 \mathrm{~g}$ dilarutkan dalam $100 \mathrm{~mL}$ akuades dan didapatkan larutan induk $1000 \mathrm{mg} / \mathrm{L}$. Larutan induk diencerkan menjadi variasi konsentrasi 2, 4, 6, 8, dan 10 $\mathrm{mg} / \mathrm{L}$. Masing-masing larutan diukur serapannya dengan spektrofotometer UV-Vis pada panjang gelombang 200$400 \mathrm{~nm}$. Data absorban diambil pada panjang gelombang yang memberikan serapan maksimum.

\subsection{Pengaruh waktu fotolisis sinar UV}

Larutan fenol $8 \mathrm{mg} / \mathrm{L}$ dimasukkan masing-masing 20 $\mathrm{mL}$ ke dalam 8 buah cawan petri. Larutan disinari dengan sinar UV dan sinar tampak pada variasi waktu 30, 60, 90, 120, 150, 180, 210 dan 240 menit. Serapan masing-masing larutan diukur dengan spektrofotometer UV-Vis pada panjang gelombang maksimum. 


\subsection{Penentuan jumlah katalis optimum}

Larutan fenol $8 \mathrm{mg} / \mathrm{L}$ dimasukkan masing-masing 20 $\mathrm{mL}$ ke dalam 4 buah cawan petri dan ditambahkan variasi katalis 1, 3, 5, dan $7 \mathrm{mg}$. Masing-masing larutan didegradasi dengan menggunakan lampu UV dan sinar tampak selama 120 menit. Setelah selesai disinari larutan disentrifus selama 30 menit dengan kecepatan $3000 \mathrm{rpm}$. Serapan masing-masing larutan diukur dengan spektrofotometer UV-Vis pada panjang gelombang maksimum, dan dihitung persen degradasinya.

\subsection{Pengaruh waktu fotokatalisis sinar UV dan sinar tampak}

Larutan fenol $8 \mathrm{mg} / \mathrm{L}$ dimasukkan masing-masing 20 $\mathrm{mL}$ ke dalam 8 buah cawan petri dan ditambahkan $5 \mathrm{mg}$ katalis C-doped $\mathrm{TiO}_{2}$. Larutan disinari dengan sinar UV dan sinar tampak pada variasi waktu 30, 60, 90, 120, 150, 180, 210 dan 240 menit kemudian disentrifus selama 30 menit dengan kecepatan $3000 \mathrm{rpm}$. Serapan masing-masing larutan diukur dengan spektrofotometer UV-Vis pada panjang gelombang maksimum, dan dihitung persen degradasinya.

\section{Hasil dan pembahasan}

\subsection{Karakterisasi katalis C-doped $\mathrm{TiO}_{2}$ dengan XRD}

Analisis pola difraksi sinar-X dilakukan untuk mengetahui struktur dan ukuran kristal dari fotokatalis C-doped $\mathrm{TiO}_{2}$. Struktur kristal C-doped $\mathrm{TiO}_{2}$ dapat diketahui dengan membandingkan difraktogram $\mathrm{C}$-doped $\mathrm{TiO}_{2}$ yang disintesis dengan difraktogram $\mathrm{TiO}_{2}$ standar (ICSD no. 9852). Gambar 1 menunjukkan adanya kesesuaian pola difraktogram $\mathrm{C}$-doped $\mathrm{TiO}_{2}$ dengan pola dari $\mathrm{TiO} 2$ standar. Puncak-puncak tersebut berada pada 20: $25,2^{\circ} ; 37,7^{\circ} ; 47,9^{\circ} ; 53,8^{\circ} ; 55,1^{\circ} ; 62,7^{\circ} ; 75,2^{\circ} ; 82,5^{\circ}$. Data ini menunjukkan bahwa C-doped $\mathrm{TiO}_{2}$ memiliki struktur kristal anatase.

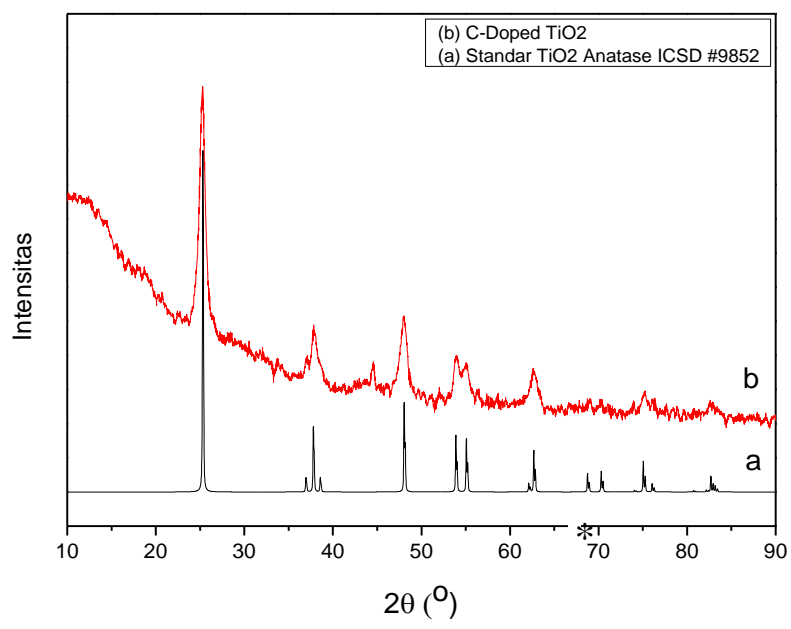

Gambar 1. Pola XRD dari C-doped TiO2 dan standar $\mathrm{TiO}_{2}$ ICSD no. 9852

Struktur kristal anatase adalah struktur kristal $\mathrm{TiO}_{2}$ yang diharapkan untuk proses degradasi senyawa fenol karena anatase memiliki luas permukaan yang lebih besar dari rutile maupun brookite. Selain itu, struktur kristal anatase memiliki kestabilan pada suhu relatif lebih rendah dari rutile dan brookite, sehingga akan lebih menguntungkan bila menggunakan $\mathrm{TiO}_{2}$ dengan struktur kristal anatase (Zhang et al., 2014).

\subsection{Karakterisasi katalis $\mathrm{C}$-doped $\mathrm{TiO}_{2}$ dengan DRS UV-Vis}

Katalis C-doped $\mathrm{TiO}_{2}$ dikarakterisasi dengan Diffuse Reflactance Spectra UV-Vis (DRS UV-Vis) untuk menentukan band gap dan pergeseran intensitas penyerapan setelah dimodifikasi. Gambar 2 menunjukkan intensitas penyerapan titania terdapat pada panjang gelombang di daerah sinar tampak. Hal ini menandakan keberhasilan karbon dalam modifikasi titania. Keberhasilan ini didukung dengan laporan yang menyatakan bahwa $\mathrm{TiO}_{2}$ hanya menyerap pada sinar UV dan karbon dapat menggeser intensitas penyerapan $\mathrm{TiO}_{2}$ ke arah sinar tampak (Wellia et al., 2018).

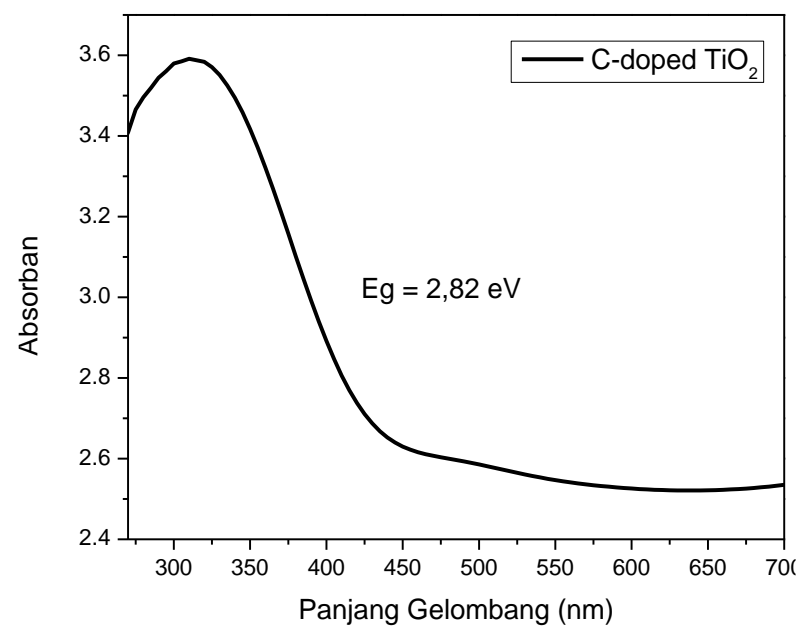

Gambar 2. Pola serapan katalis C-doped $\mathrm{TiO}_{2}$ pada DRS UV-Vis

Pergeseran serapan titania ke daerah sinar tampak disebabkan oleh pengaruh modifikasi, dimana keadaan dasar dari elektron yang tersebar pada band gap mengalami pergeseran penyerapan spektrum sehingga nilai band gap mengalami penurunan dibandingkan dengan tanpa modifikasi. Hal ini dapat memenuhi kebutuhan pembuatan katalis titania yang mampu menyerap dan aktif pada sinar tampak (Gupta and Tripathi, 2011).

\subsection{Pengukuran spektrum serapan senyawa fenol}

Pada Gambar 3 memperlihatkan hasil pengukuran serapan senyawa fenol dan didapatkan serapan maksimum pada panjang gelombang $269 \mathrm{~nm}$ (Steiner, 2017). Pada pengukuran larutan fenol menggunakan spektrofotometer UV-Vis, nilai absorban yang didapatkan pada konsentrasi 2, 4, 6, 8, dan $10 \mathrm{mg} / \mathrm{L}$ secara berturut-turut adalah 0,$016 ; 0,047 ; 0,085 ; 0,118$; dan 0,154 . Untuk perlakuan selanjutnya digunakan larutan fenol $8 \mathrm{mg} / \mathrm{L}$ sebagai konsentrasi awal sampel 
untuk didegradasi secara fotolisis di bawah sinar UV $(\lambda=$ $365 \mathrm{~nm}$ ) dan sinar tampak.

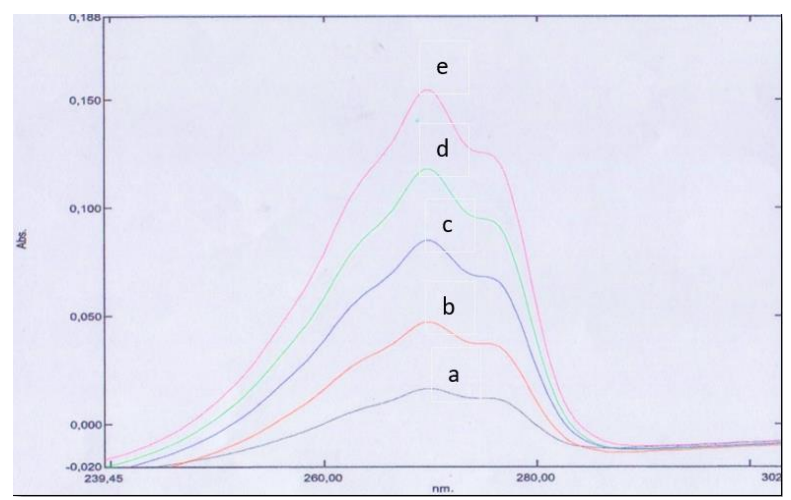

Gambar 3. Spektrum serapan maksimum larutan standar fenol pada konsentrasi (a) $2 \mathrm{mg} / \mathrm{L}$, (b) $4 \mathrm{mg} / \mathrm{L}$, (c) 6 $\mathrm{mg} / \mathrm{L}$, (d) $8 \mathrm{mg} / \mathrm{L}$, (e) $10 \mathrm{mg} / \mathrm{L}$ pada panjang gelombang $269 \mathrm{~nm}$.

\subsection{Pengaruh waktu terhadap degradasi fenol secara fotolisis}

Fotolisis dilakukan terhadap larutan fenol pada konsentrasi $8 \mathrm{mg} / \mathrm{L}$ dengan variasi waktu 30, 60, 90, 120, 150, 180, 210, dan 240 menit menggunakan sumber lampu UV $(\lambda=365 \mathrm{~nm})$ dan sinar tampak. Pengaruh waktu fotolisis dengan lampu UV $(\lambda=365 \mathrm{~nm})$ dan lampu sinar tampak terhadap persen degradasi dapat diamati pada Gambar 4.

Dari Gambar 4 dapat dilihat bahwa semakin lama proses degradasi maka persentase degradasi semakin meningkat. Hal ini dikarenakan semakin lama penyinaran maka semakin banyak senyawa-senyawa yang mengalami penguraian oleh energi foton dari sinar UV dan sinar tampak (Alalm and Tawfik, 2014). Persen degradasi fenol dengan penyinaran selama 240 menit menggunakan sinar tampak yaitu sebesar 35,59\% dan pada penyinaran sinar UV $(\lambda=365 \mathrm{~nm})$ sebesar $38,98 \%$.

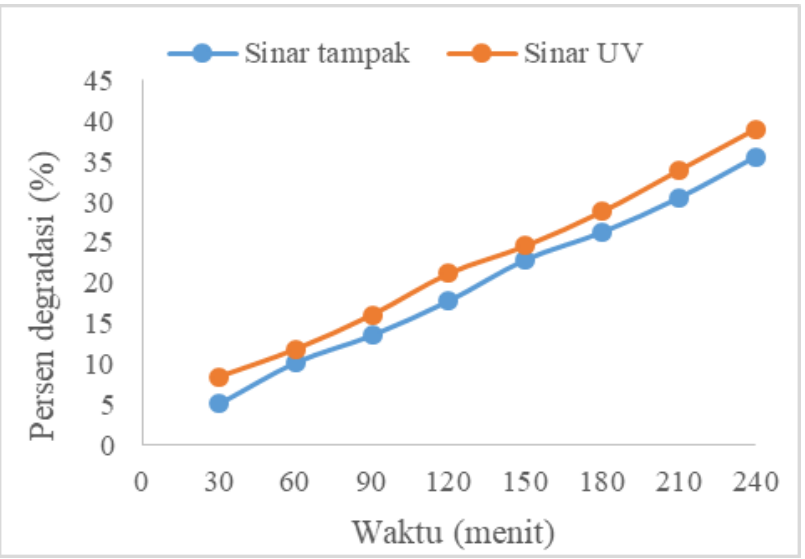

Gambar 4. Pengaruh waktu dan sumber sinar terhadap degradasi $8 \mathrm{mg} / \mathrm{L}$ fenol selama (30-240) menit fotolisis

\subsection{Pengaruh sumber sinar terhadap persen degradasi fenol tanpa katalis}

Persen degradasi fenol secara fotolisis di bawah penyinaran lampu UV $(\lambda=365 \mathrm{~nm})$ dan lampu sinar tampak tanpa penambahan katalis dapat dilihat pada Gambar 4. Persen degradasi fenol dengan lampu sinar tampak lebih kecil jika dibandingkan dengan lampu UV. Hal ini dikarenakan lampu sinar tampak memiliki energi yang lebih kecil dibandingkan sinar UV sehingga kemampuan untuk mendegradasi senyawa organik juga rendah (Reza et al., 2015). Sesuai dengan hukum Planck yang menyatakan bahwa energi foton berbanding terbalik dengan panjang gelombang, dimana sinar UV yang digunakan memiliki panjang gelombang pendek (365 nm) dari pada sinar tampak (400-800nm). Peneliti lainnya melaporkan hanya $2 \%$ dan $16 \%$ fenol yang terdegradasi secara fotolisis UV (Mohamed et al., 2015; $\mathrm{Mu}$ et al., 2016). Perbedaan hasil yang didapatkan kemungkinan disebabkan oleh kondisi eksperimen yang berbeda.

\subsection{Penentuan massa optimum katalis C-doped $\mathrm{TiO}_{2}$ dalam proses degradasi}

Massa katalis C-doped $\mathrm{TiO}_{2}$ yang digunakan dalam proses degradasi ditentukan dengan memvariasikan massa katalis C-doped $\mathrm{TiO}_{2}$ yaitu 1, 3, 5, dan $7 \mathrm{mg}$. Fenol didegradasi secara fotokatalisis dengan menambahkan 1-7 mg katalis C-doped $\mathrm{TiO}_{2}$ selama 120 menit iradiasi. Pengaruh massa katalis C-doped $\mathrm{TiO}_{2}$ terhadap persen degradasi fenol dapat dilihat pada Gambar 5. Pada grafik memperlihatkan bahwa persentase degradasi meningkat secara signifikan dengan bertambahnya jumlah katalis dari 1 - 5 mg. Hal ini disebabkan oleh peningkatan jumlah katalis menyebabkan sisi aktif permukaan meningkat sehingga jumlah foton dan molekul senyawa fenol yang diadsorpsi di permukaan katalis juga semakin banyak (Alalm and Tawfik, 2014). Akan tetapi, pada penambahan $7 \mathrm{mg}$ katalis, tidak terjadi kenaikan persen degradasi yang terlalu besar/tidak signifikan. Hal ini terjadi karena katalis yang diberikan dalam jumlah banyak menyebabkan larutan menjadi jenuh dan keruh, penghamburan sinar, dan penurunan penetrasi sinar sehingga menurunkan efisiensi degradasi (Alalm and Tawfik, 2014). Persentase degradasi senyawa fenol dengan penambahan katalis $5 \mathrm{mg}$ secara fotolisis selama 120 menit sebesar $24,57 \%$ pada penyinaran sinar UV dan $33,05 \%$ pada penyinaran sinar tampak.

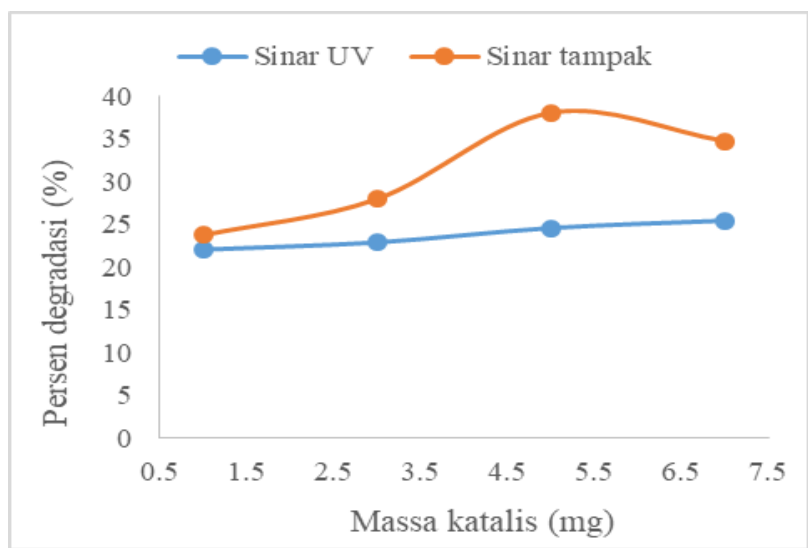

Gambar 5. Pengaruh massa katalis terhadap degradasi 8 $\mathrm{mg} / \mathrm{L}$ fenol menggunakan $5 \mathrm{mg}$ katalis C-doped $\mathrm{TiO}_{2}$ selama 120 menit fotokatalisis 


\subsection{Pengaruh katalis terhadap persen degradasi fenol}

Perbandingan persen degradasi fenol tanpa katalis dan dengan penambahan $5 \mathrm{mg}$ katalis $\mathrm{C}$-doped $\mathrm{TiO}_{2}$ secara fotokatalisis dengan lampu UV $(\lambda=365 \mathrm{~nm})$ dan lampu sinar tampak dapat dilihat pada Gambar 6 dan 7.

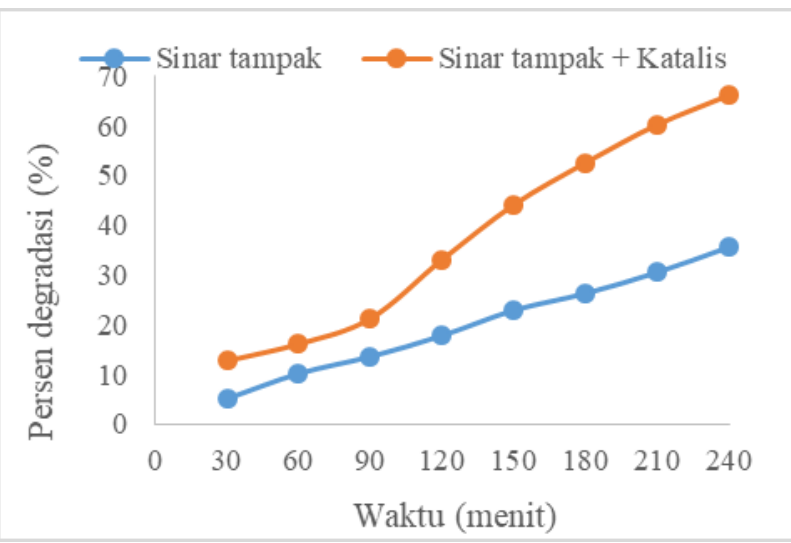

Gambar 6. Pengaruh katalis terhadap degradasi $8 \mathrm{mg} / \mathrm{L}$ fenol secara fotolisis dan fototkatalisis menggunakan 5 mg katalis $\mathrm{C}$-doped $\mathrm{TiO} 2$ diiradiasi sinar tampak

Pada Gambar 6 dapat dilihat bahwa jumlah degradasi fenol meningkat dengan adanya penambahan katalis dan peningkatan waktu iradiasi. Fenol terdegradasi sebanyak $35,59 \%$ tanpa katalis di bawah sinar tampak, dan meningkat menjadi $66,10 \%$ dengan penambahan katalis. Ketika katalis C-doped $\mathrm{TiO}_{2}$ disinari dengan sinar tampak, elektron $\mathrm{TiO}_{2}$ akan tereksitasi dari pita valensi ke pita konduksi yang menghasilkan radikal $\mathrm{OH} \bullet$. Spesies reaktif inilah yang mengoksidasi fenol sehingga ketika ditambahkan katalis pada sistem fotokatalisis, konsentrasi radikal menjadi meningkat dan menyebabkan penigkatan persen degradasi fenol.

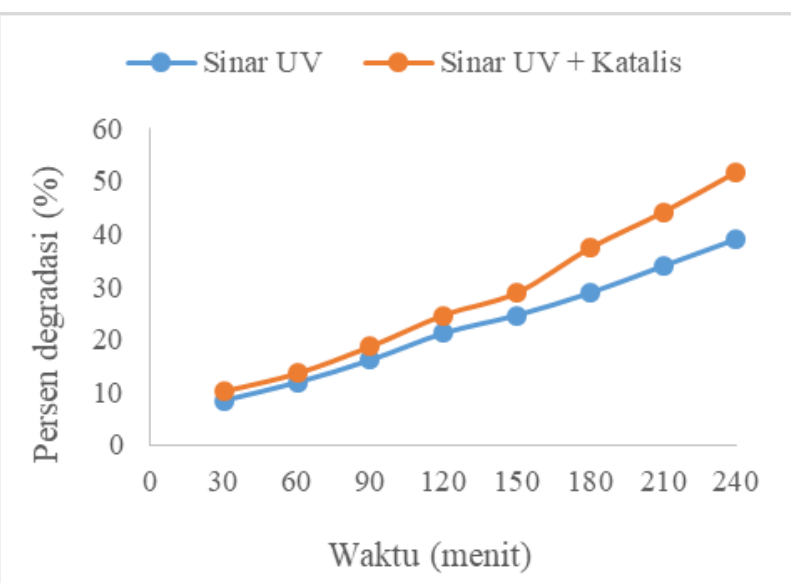

Gambar 7. Pengaruh katalis terhadap degradasi $8 \mathrm{mg} / \mathrm{L}$ fenol secara fotolisis dan fotokatalisis menggunakan 5 mg katalis C-doped $\mathrm{TiO}_{2}$ yang diiradiasi dengan sinar UV

Pada penyinaran 30 menit, fenol terdegradasi $12,7 \%$ meningkat menjadi $66,10 \%$ pada 240 menit fotokatalisis. Hal ini disebabkan karena semakin lama waktu penyinaran maka semakin banyak sinar tampak yang mengenai katalis C-doped $\mathrm{TiO}_{2}$, sehingga semakin banyak $\mathrm{OH} \bullet$ yang dihasilkan untuk mendegradasi fenol (Alalm and Tawfik, 2014).

Pola yang sama juga didapatkan pada degradasi fenol di bawah sinar UV bahwa efisiensi degradasi meningkat dengan adanya katalis dan lama waktu iradiasi. Persen degradasi fenol pada penyinaran 30-240 menit adalah $10,17 \%$ - 51,69\% seperti yang tergambar pada Gambar 7. Hasil membuktikan bahwa lama penyinaran mampu meningkatkan aktivitas fotokatalitik C-doped $\mathrm{TiO}_{2}$ dan katalis berperan penting dalam proses degradasi karena persen degradasi yang didapatkan lebih besar dibandingkan pada sistem tanpa penambahan katalis Cdoped $\mathrm{TiO}_{2}$ (Alalm and Tawfik, 2014). Persen degradasi yang dihasilkan dari proses tanpa katalis 38,98\% dan dengan penambahan katalis sebesar 51,69\% selama 240 menit fotokatalisis di bawah sinar UV.

\subsection{Pengaruh sinar terhadap persentase degradasi fenol dengan penambahan katalis $\mathrm{C}$-doped $\mathrm{TiO}_{2}$}

Fotokatalisis dilakukan terhadap larutan fenol pada konsentrasi $8 \mathrm{mg} / \mathrm{L}$ dengan massa katalis $5 \mathrm{mg}$ dan dilakukan pada variasi waktu 30, 60, 90, 120, 150, 180, 210, dan 240 menit menggunakan sumber lampu UV ( $\lambda$ $=365 \mathrm{~nm}$ ) dan sinar tampak, serta tanpa sinar.

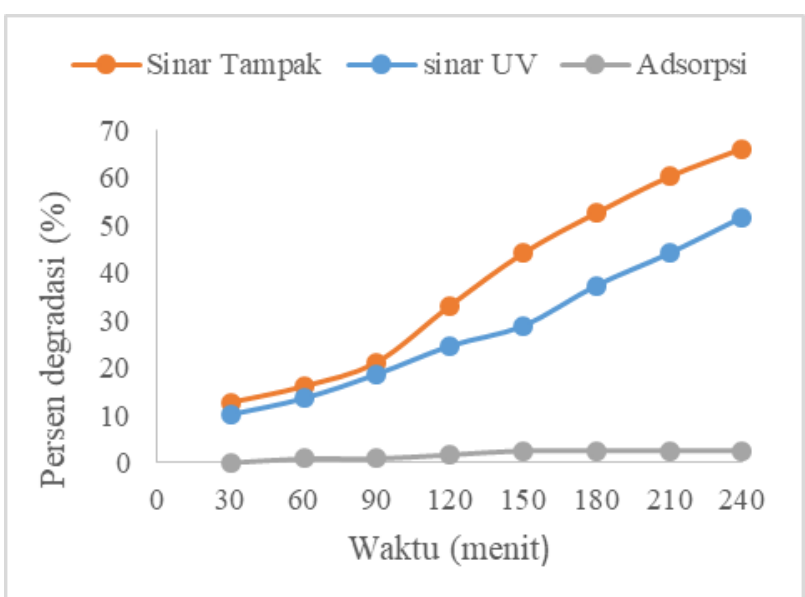

Gambar 8. Perbandingan persentase degradasi $8 \mathrm{mg} / \mathrm{L}$ fenol secara fotokatalisis menggunakan $5 \mathrm{mg}$ katalis Cdoped $\mathrm{TiO}_{2}$ di bawah sinar UV, sinar tampak dan tanpa sinar

Perbandingan persen degradasi fenol secara fotokatalisis dengan lampu UV $(\lambda=365 \mathrm{~nm})$ dan lampu sinar tampak dapat dilihat pada Gambar 8. Fotokatalis Cdoped $\mathrm{TiO}_{2}$ dapat mendegradasi dengan baik di bawah sinar tampak. Hal ini disebabkan oleh keberadaan karbon yang berhasil menurunkan band gap $\mathrm{TiO}_{2}$ sehingga $\mathrm{TiO}_{2}$ dapat diaktivasi di bawah sinar tampak dan proses degradasi fenol menjadi lebih maksimal. Selain itu, peran lain dari karbon adalah berperan sebagai photosensitizer yang dapat menangkap cahaya pada daerah panjang gelombang sinar tampak (Wu et al., 2011). Sebagai kontrol, kemampuan adsorpsi dari katalis juga dilakukan. Hasil adsorpsi fenol terhadap katalis adalah sebesar 0 - 2,54\% selama 30 - 240 menit. Hasil ini mengkonfirmasikan bahwa degradasi fenol dominan dari proses oksidasi oleh radikal $\mathrm{OH} \bullet$ yang dihasilkan 
dari reaksi katalis dan sinar tampak pada sistem fotokatalisis di bawah sinar tampak.

\section{Kesimpulan}

Berdasarkan penelitian yang telah dilakukan maka dapat disimpulkan bahwa katalis modifikasi titania dengan karbon (C-doped $\mathrm{TiO}_{2}$ ) menggunakan metode peroxo sol-gel dapat diaplikasikan untuk degradasi senyawa fenol. Katalis ini dapat aktif pada sinar UV dan sinar tampak, serta mampu meningkatkan efisiensi degradasi fenol pada sistem fotokatalisis. Larutan fenol 8 $\mathrm{mg} / \mathrm{L}$ terdegradasi sebanyak $38,98 \%$ dan $35,59 \%$ tanpa katalis dan meningkat menjadi $51,69 \%$ dan $66,10 \%$ dengan penambahan $5 \mathrm{mg}$ katalis $\mathrm{C}$-doped $\mathrm{TiO}_{2}$ masingmasing di bawah sinar UV dan sinar tampak selama 240 menit penyinaran. Degradasi fenol sangat dipengaruhi oleh massa katalis, sumber sinar dan waktu iradiasi. Peningkatan efisiensi degradasi dengan adanya katalis mampu memberikan sumber produksi radikal $\mathrm{OH} \bullet$ yang lebih banyak. Keberadaan unsur karbon menyebabkan penurunan band gap $\mathrm{TiO}_{2}$ sehingga katalis mampu menyerap sinar tampak dan proses degradasi fenol menjadi lebih maksimal di bawah sinar tampak.

\section{Daftar pustaka}

Abdelwahab, O., Amin, N.K., El-Ashtoukhy, E.S.Z., 2009. Electrochemical removal of phenol from oil refinery wastewater. J. Hazard. Mater. 163, 711716.https://doi.org/10.1016/j.jhazmat.2008.07.016

Alalm, M., Tawfik, A. 2014. Solar photocatalytic degradation of phenol in aqueous solutions using titanium dioxide. Waset.Org 1-4.

Arfi, F., Safni, S., Abdullah, Z., 2018. Degradation of paraquat in gramoxone pesticide with addition of ZnO. Molekul 12, 159. https://doi.org/10.20884/1.jm. 2017.12.2.326

Borji, S.H., Nasseri, S., Mahvi, A.H., Nabizadeh, R., Javadi, A.H., 2014. Investigation of photocatalytic degradation of phenol by $\mathrm{Fe}(\mathrm{III})$-doped $\mathrm{TiO}_{2}$ and $\mathrm{TiO}_{2}$ nanoparticles. J. Environ. Heal. Sci. Eng. 12, 110. https://doi.org/10.1186/2052-336X-12-101

Gupta, S.M., Tripathi, M., 2011. A review of $\mathrm{TiO}_{2}$ nanoparticles. Chinese Sci. Bull. 56, 1639-1657. https://doi.org/10.1007/s11434-011-4476-1

Jyothi, K.P., 2016. Advanced oxidation processes in wastewater treatment: Investigations on the phenomenon of oscillation in the concentration of concurrently formed $\mathrm{H}_{2} \mathrm{O}_{2}$ in sono, photo and sonophoto catalytic systems. Thesis submitted to Cochin University of Science and. Cochin University of Science and Technology.

Khalid, N.R., Majid, A., Tahir, M.B., Niaz, N.A., Khalid, S., 2017. Carbonaceous- $\mathrm{TiO}_{2}$ nanomaterials for photocatalytic degradation of pollutants: A review. Ceram. Int. 43, 14552-14571. https://doi.org/10.1016/j.ceramint.2017.08.143

Kumar, N.S., Min, K., 2011. Removal of phenolic compounds from aqueous solutions by biosorption onto acacia leucocephala bark powder: Equilibrium and kinetic studies. J. Chil. Chem. Soc. 56, 539-545.
Mariappan, G., Vijayan, P., Suresh, C., Shanthi, K., 2014. Titania nanoparticles modified with nitrogen: enhanced visible-light photocatalytic activity. J. Environ. Nanotechnol 3, 2319-5541. https://doi.org/ 10.13074/jent.2014.12.144111

Meena, M.C., Band, R., Sharma, G., 2015. Phenol and its toxicity: A case report. Iran. J. Toxicol. 8, 12221224.

Mohamed, M.A., Salleh, W.N.W., Jaafar, J., Ismail, A.F., Nor, N.A.M., 2015. Photodegradation of phenol by $\mathrm{N}$-Doped $\mathrm{TiO}_{2}$ anatase/rutile nanorods assembled microsphere under UV and visible light irradiation. Mater. Chem. Phys. 162, 113-123. https://doi.org/10.1016/j.matchemphys.2015.05.033

$\mathrm{Mu}$, M.J., Fontelles-carceller, O., Ferrer, M., Fernándezgarcía, M., Kubacka, A., 2016. Environmental disinfection capability of $\mathrm{Ag} / \mathrm{g}-\mathrm{C}_{3} \mathrm{~N}_{4}$ composite photocatalysts under UV and visible light illumination. Appl. Catal. B Environ. 183, 86-95. https://doi.org/10.1016/j.apcatb.2015.10.024

Reza, K.M., Kurny, A., Gulshan, F., 2015. Parameters affecting the photocatalytic degradation of dyes using $\mathrm{TiO}_{2}$ : a review. Appl. Water Sci. 7, 1569-1578. https://doi.org/10.1007/s13201-015-0367-y

Safni, M., Putri, R.A., Wellia, D.V., Septiani, U., 2017. Photodegradation of Orange F3R Dyes: Effect of light sources and the addition of $\mathrm{C}, \mathrm{N}$ - codoped $\mathrm{TiO}_{2}$. $9,1-5$.

Safni, S., Anggraini, D., Wellia, D., Khoiriah, K., 2015. Degradation of direct red-23 and direct violet dyes by ozonolysis and photolysis methods with uv light and solar irradiation using $\mathrm{N}$-doped $\mathrm{TiO}_{2}$ Catalyst. J. Litbang Ind. 5, 123-130.

Safni, Wellia, D.V., Komala, P.S., Putri, R.A., 2015. Degradation of yellow-GCN by photolysis with UVlight and solar irradiation using C-N-codoped $\mathrm{TiO}_{2}$ catalyst. J. Chem. Pharm. Res. 7, 306-311.

Sharma, S., Ruparelia, J., Patel, M., 2011. A general review on advanced oxidation processes for waste water treatment. Int. Conf. Curr. trends Technol. 810.

Steiner, M.G., 2017. Photocatalytic decomposition of phenol under visible and uv light utilizing titanium dioxide based catalysts photocatalytic decomposition of phenol under visible and UV light.

Teh, C.M., Mohamed, A.R., 2011. Roles of titanium dioxide and ion-doped titanium dioxide on photocatalytic degradation of organic pollutants (phenolic compounds and dyes) in aqueous solutions: A review. J. Alloys Compd. 509, 16481660.https://doi.org/10.1016/j.jallcom.2010.10.181

Wellia, D.V., Fitria, D., Safni, S., 2018. C-N-Codoped $\mathrm{TiO}_{2}$ synthesis by using peroxo sol gel method for photocatalytic reduction of $\mathrm{Cr}(\mathrm{VI})$. J. Pure Appl. Chem. Res. 7, 26-32. https://doi.org/10.21776/ ub.jpacr.2018.007.01.373

Wiley, J., Sons, 2003. The chemistry of phenols, Chapter 7. An Interscience ${ }^{\circledR}$ Publication.

Wu, Y., Xing, M., Zhang, J., 2011. Gel-hydrothermal synthesis of carbon and boron co-doped $\mathrm{TiO}_{2}$ and evaluating its photocatalytic activity. J. Hazard. Mater. 192, 368-373. https://doi.org/10.1016/ j.jhazmat.2011.05.037 
Degradasi senyawa fenol secara fotokatalisis ....... (Safni et al.)

Yunus, N.N., Hamzah, F., So'Aib, M.S., Krishnan, J., 2017. Effect of catalyst loading on photocatalytic degradation of phenol by using $\mathrm{N}, \mathrm{S}$ Co-doped $\mathrm{TiO}_{2}$. IOP Conf. Ser. Mater. Sci. Eng. 206. https://doi.org/10.1088/1757-899X/206/1/012092
Zhang, J., Zhou, P., Liu, J., Yu, J., 2014. New understanding of the difference of photocatalytic activity among anatase, rutile and brookite $\mathrm{TiO}_{2}$. Phys. Chem. Chem. Phys. 16, 20382-20386. https://doi.org/10.1039/c4cp02201g 